\title{
THE OFFENCE OF TERRORIST FINANCING; WHY DOES IT GO WRONG?
}

\author{
Hamed Tofangsaz* \\ PhD Candidate, Te Piringa - Faculty of Law, University of Waikato, Hamilton, New Zealand
}

\begin{abstract}
The international convention on terrorist financing and Western-backed international organizations have found the financing of terrorism serious enough to criminalize it as an independent offence. While the offence has a preparatory nature, its criminalization as an independent offence expands the boundary of criminal liability beyond existing notions of criminalization. This paper aims at examining the justifiability of the terrorist financing offence with regard to the principles and values on which liberal criminal law is based. Liberal criminal law has been chosen because the idea of the criminalization of terrorist financing was issued and developed mainly by Western liberal states. The paper narrowly discusses the issue in the context of Anglo-American criminal law.
\end{abstract}

Keywords: Terrorist financing, liberal criminal law, criminalization, offence

\section{Introduction}

The idea of using criminal law to suppress terrorist financing was conceived, proposed, developed and is supported by Western states. In 1995, a call for the adoption of measures to counter terrorist financing was officially issued in G7/8 ministerial meetings. ${ }^{1}$ In 1999, a draft of a convention on terrorist financing, a French initiative at a G8 summit, ${ }^{2}$ was proposed to the United Nations. ${ }^{3}$ The draft regarded terrorist financing as "a matter of grave concern to the international community", ${ }^{4}$ which needs to be tackled independently. After two weeks of negotiations, the International Convention for the Suppression of the Financing of Terrorism

\footnotetext{
* PhD candidate at the Faculty of Law, University of Waikato, New Zealand. The author can be contacted at: hamedtofangsaz@gmail.com. This is the pre-peer-review version of the manuscript.

${ }^{1}$ G7 Ottawa Ministerial Declaration on Countering Terrorism (December 12, 1995). See also G7 Ministerial Conference on Terrorism (Paris, July 30, 1996). The role of G8 in the fight against terrorism is significant, as its members declared that "we are determined as a group to continue to provide leadership on this issue to the international community, using bilateral and multilateral measures and agreements to counter terrorism". For more information about the role of the G8 in the fight against terrorism, see Andre Belelieu "The G8 and terrorism: what role can the G8 play in the 21st century?” June 2002 No. 8 G8 Governance.

${ }^{2}$ G8 Foreign Ministers' Progress Report: Denver Summit of the Eight (Denver, June 21, 1997). For more details on the French initiative at the Denver summit see Andre Belelieu "The G8 and terrorism: what role can the G8 play in the 21st century?” June 2002 No. 8 G8 Governance. < http://www.g8.utoronto.ca/governance/ >; Michele Fratianni New perspectives on global governance : why America needs the G8 (Ashgate, Aldershot, 2005).

${ }^{3}$ UN Doc Letter dated 3 November 1998 from the Permanent Representative of France to the United Nations addressed to the Secretary-general (A/C.6/53/9,4 November 1998).

${ }^{4}$ United Nations The International Convention for the Suppression of the Financing of Terrorism (New York, 9 December 1999), (hereinafter Terrorist Financing Convention), Preamble.
} 
(hereinafter Terrorist Financing Convention) was adopted and the offence of terrorist financing was introduced. After the 9/11 attacks, the Financial Action Task Force (hereinafter FATF), an inter-governmental body established by the G7/8 in 1989 to counter money laundering, was tasked with setting out "in detail the specific elements required to comply with the obligation to criminalise terrorist financing based on" the Terrorist Financing Convention. ${ }^{5}$ Under the Convention and the guidance of the FATF's recommendations, states are asked to criminalize terrorist financing without a link to, or the existence of, a terrorist act. ${ }^{6}$ But the question arises: why should terrorist financing, which is an ancillary form of participation in another crime (terrorism), be criminalized as an independent offence if the laws of inchoate offences and complicity can properly deal with it?

In general, in anti-terrorist legislation, the main rationale for targeting preparatory conduct and criminalizing them as a stand-alone offence stems from the need "to defend further up the field". ${ }^{7}$ In other words, the ability to defend further up the field, which is a footballing phrase, should be advanced due to "a consequence of the highly destructive potential of single, concentrated terrorist attacks; the danger of allowing such a plot to run; and so the resulting need to intervene at an earlier stage" ${ }^{8}$ Defending further up the filed in practice means "earlier criminalization, earlier interventions by law enforcers, and earlier and more intrusive policing, much closer to everyday behaviour". ${ }^{9}$

The terrorist financing offence was created with the same rationale. The offence permits criminalization of the collection or provision of funds when they are carried out with the knowledge or intention that the funds will be used for preparation of a terrorist act, or used by terrorists or terrorist groups "for any purposes". ${ }^{10}$ This extends the reach of criminal law so far so as to include a broad range of conduct which falls short of constituting attempt, conspiracy or incitement.

It should be noted that such criminalization is not limited to terrorist-related offences. ${ }^{11}$ For instance, in Australia, it is an offence to connect "equipment to a telecommunication network"

\footnotetext{
${ }^{5}$ FATF “FATF guidance: crimialising terrorist financing (Recommendation 5)” Octover 2016, Para.1.

${ }^{6}$ See Article 2 of Terrorist Financing Convention. Or FATF "International standards on combating money laundering and the financing of terrorism \& proliferation”( February 2012), P.11.

${ }^{7}$ David Anderson QC "Shielding the compass: how to fight terrorism without defeating the law" 20133

European Human Rights Law Review 233.

${ }^{8}$ Ibid, P.6.

${ }^{9}$ Andrew Ashworth and Lucia Zedner Preventive Justice (Oxford University Press, Oxford, UK, 2014), P. 118.

${ }^{10}$ FATF, above n 5, Para. 22.

${ }^{11}$ Ashworth and Zedner, above n 9, p. 99
} 
with intention "to commit, or facilitate the commission of", "a serious offence of the Commonwealth”. ${ }^{12}$ Or in UK, it is an offence to meet, or travel to meet, a child for the purpose of person committing a child sex offence. ${ }^{13}$ In both offences the defendant's purpose of committing a substantive offence allows early intervention and criminalization of conduct which is very distant from the substantive offence.

Is such an approach to criminalization justifiable? There are many different possible ways to argue whether such an approach can be justified. It is beyond the scope of this paper to identify all of them and discuss their merits. The purpose of the paper is to examine the justifiability of the terrorist financing offence with regard to the principles and values on which liberal criminal law is based. I have chosen the values of liberal criminal law as a yardstick because the idea of criminalization of terrorist financing was proposed and developed mainly by Western liberal states. The diffusion of these criminalization measures is overwhelmingly supported by them or the inter-governmental or international organizations backed up by them. It is apt, therefore, to engage in a normative analysis of this offence against the values said to underpin Western criminal law. For purposes of convenience, the paper narrowly discusses the issue in the context of Anglo-American criminal law.

In the next section, the spectrum of terrorist financing offences, their scope and their elements are explained. Then, the role of liberal criminal law is briefly discussed. The values, principles and policies that should have influence on shaping substantive criminal law are explored. In the final part, four main principles that should be deployed in evaluating the justifiability of creating of a candidate offence are examined. These principles are the principle of harm, the wrongful requirement, the remoteness requirement, and rule of law standards. Whether the terrorist financing offence satisfies the standard criteria of criminalization provided by these principles is discussed, and as a result a determination is made about the justifiability of the offence on these principles.

This paper is of opinion that no argument in support of the offence should outweigh, or be regarded more important than, the arguments favouring these values and principles since they are the compasses of the society that must continue to evolve in order for us to "keep up our bearings". ${ }^{14}$ This does not mean at all to suggest that special rules should not be adopted for

\footnotetext{
${ }^{12}$ Criminal Code Act 1995 (Australia), Article 474.14

${ }^{13}$ Sexual Offences Act 2003 (UK), Section 15.

${ }^{14}$ Anderson QC, above n 7, P. 19
} 
exceptional situations when existential threats are involved. However, it is controversial to consider terrorism as an existential threat, as well as to think that, if terrorism was a threat to our existence, the derogation from these principles and values would be justified. Andrew Simester captures the point well:

Western Europeans will recall many acts of terrorism across the past four decades that did not pose such a risk. Until there are cogent reasons for thinking that the terrorist threat has reached that stage, acts of terrorism should be treated as criminal conduct in ordinary way. Moreover, even if existential threats were real, it would not follow that exceptional criminal-law responses should be adopted. If and when that juncture is reached, the way forward will be to address such dangers by emergency mechanisms of the kind appropriate to other radical events such as natural disasters, the spread of a virulent, non-treatable diseases, or international war. At least in the existence of making wrongs criminal, it is a moral mistake to think that, when existence is threatened, the gloves may come off and anything goes. ${ }^{15}$

\section{Spectrum of terrorist financing offences}

Terrorist financing is a term used to include two types of conduct: financing of a terrorist act, financing of a person or an organization who or which intends to commit or prepare for a terrorist act, or who or which is designated as terrorist. While from a traditional criminal law perspective, these acts are preparatory in their nature in the sense of facilitating a substantive offence (a terrorist act), the Terrorist Financing Convention and FATF's recommendations conceptualize them as an independent offence. In this part, they will be categorised into two groups of offences: financing of a terrorist act and financing of a terrorist person or an organization.

\subsection{Financing of a terrorist act}

According to the Terrorist Financing Convention, the independent offence of terrorist financing refers to the financing of terrorist acts. The Convention introduces the terrorist financing offence as an act of collection or provision of funds when it is carried out with the knowledge or intention that the funds are to be used for the commission of a terrorist act. ${ }^{16}$ FATF emphasizes that the criminalization of the financing of terrorist acts "solely on the basis of aiding and abetting, attempt, or conspiracy is not sufficient to comply with" their

\footnotetext{
${ }^{15}$ A. P. Simester "Prophylactic crimes" in G R Sullivan and Ian. Dennis (eds) Seeking security: pre-empting the commission of criminal harms (Oxford: Hart Publishing, 2012), P. 59-60.

${ }^{16}$ Terrorist Financing Convention, Article 2.
} 
Recommendations." ${ }^{17}$ Both Convention and the FATF's Recommendations emphasize that "terrorist financing offences should not require that the funds or other assets: (a) were actually used to carry out a terrorist act(s) ${ }^{18}$; or (b) "be linked to a specific terrorist act(s)." ${ }^{19}$ According to the FATF's “guidance on criminalising terrorist financing”, this means that the financing of a terrorist act includes

instances where the terrorist financier intended to finance a terrorist act, but no terrorist act was in fact carried out or attempted (e.g. because a planned terrorist act was prevented; or because no specific act had been planned; or because the funds or other assets intended for use in a terrorist act were in fact used for some other activity. ${ }^{20}$

Understandably, the nexus between financing/funds and their subsequent terrorist act is not required in order for the offence to stand as an independent offence; otherwise the offence would fall into the category of inchoate offences or offence of complicity. ${ }^{21}$ As a result, the offence is defined so broadly in order to include any conduct carried out to facilitate commission or preparation of a terrorist act at some uncertain point; ${ }^{22}$ so, it includes the following examples:

Example 1- Buying a map of a city with the intent to prepare or plan for a terrorist act. ${ }^{23}$

Example 2- Possessing information about how to make explosives with the intent to commit a terrorist act. ${ }^{24}$

\footnotetext{
${ }^{17}$ FATF, above n 6, P. 37.

18 Terrorist Financing Convention, Article 2(3)

${ }^{19}$ FATF, above n 6, p.17

${ }^{20}$ FATF, above n 5, Para. 56

${ }^{21}$ Hamed Tofangsaz "Criminalization of Terrorist Financing; From Theory to Practice” 2018 21(1) New Criminal Law Review 57, P. 78.

22 Such a formulation found its way into domestic legislations. For example Section 16 of the Terrorism Act 2000 (UK) states“[a] person commits an offence if he (a) possesses money or other property, and (b) intends that it should be used, or has reasonable cause to suspect that it may be used, for the purposes of terrorism”. Or Section 5 of the Terrorism Act 2006 (UK) says that "[a] person commits an offence if, with the intention of ... committing acts of terrorism, or ... assisting another to commit such acts, he engages in any conduct in preparation for giving effect to his intention. It is irrelevant for the purposes of [this provision] whether the intention and preparations relate to one or more particular acts of terrorism, acts of terrorism of a particular description or acts of terrorism generally”. Similar provisions can be seen in Section 101.6(1) of the Australian Penal Code and Section 83.19 of the Canadian Penal Code.

${ }^{23}$ This example is similar to the Australian case R v Lodhi (2006), 199 FLR 364, in which the accused was charged and convicted for collecting (purchasing) of two maps of the Australian electricity supply system in preparation of a terrorist act, possessing information regarding the ingredients for and the method of manufacture of explosives in preparation for a terrorist act, and seeking a price list of chemicals for the use of explosives for a terrorist act.

${ }^{24}$ Under Section 57(1) of the Terrorism Act 2000 (UK): “[a] person commits an offence if he possesses an article in circumstances which give rise to a reasonable suspicion that his possession is for a purpose connected with the commission, preparation or instigation of an act of terrorism”.
} 
Example 3- Buying dangerous substance to rob a bank with the intent to use the robbed money for the preparation of a terrorist act.

Example 4- Going to the gym in order to get fit for the preparation or commission of a terrorist act.

\section{2 financing of an individual terrorist or a terrorist organization}

The Terrorist Financing Convention does not address the financing of terrorists and terrorist groups directly. The Convention only calls on all states to take the preventive measures to counter "the financing of terrorists and terrorist organizations". ${ }^{25}$ FATF, nonetheless, calls upon countries to extend the scope of the offence of terrorist financing to include conduct carried out by "any person who wilfully provides or collects funds or other assets by any means, directly or indirectly, with the unlawful intention that they should be used, or in the knowledge that they are to be used ... by a terrorist organisation; or ... by an individual terrorist ... for any purpose". ${ }^{26}$ The FATF's guidance on this offence is as follows.

The FATF has not provided a generic definition of terrorists or terrorist groups. ${ }^{27}$ According to FATF's recommendations, these terms refer to "an organisation or individual that commits, attempts, or is otherwise complicit in a terrorist act”. ${ }^{28}$ An individual or organization can also be designated as terrorist by the decision made by national authorities or UN Sanction Committee on the basis of the information or intelligence they receive without any judicial process.

The term "for any purpose" means that

the terrorist financier must be acting with the knowledge that the funds or other assets are to be provided or collected for a terrorist organisation or individual terrorist; and (b) it is only the

\footnotetext{
25 Terrorist Financing Convention, Preamble.

${ }^{26}$ FATF, above n 6, P. 37

${ }^{27}$ Under FATF's recommendations, the term terrorist refers to "any natural person who: (i) commits, or attempts to commit, terrorist acts by any means, directly or indirectly, unlawfully and wilfully; (ii) participates as an accomplice in terrorist acts ; (iii) organises or directs others to commit terrorist acts ; or (iv) contributes to the commission of terrorist acts by a group of persons acting with a common purpose where the contribution is made intentionally and with the aim of furthering the terrorist act or with the knowledge of the intention of the group to commit a terrorist act". And the term terrorist group refer to "any group of terrorists that: (i) commits, or attempts to commit, terrorist acts by any means, directly or indirectly, unlawfully and wilfully; (ii) participates as an accomplice in terrorist acts; (iii) organises or directs others to commit terrorist acts; or (iv) contributes to the commission of terrorist acts by a group of persons acting with a common purpose where the contribution is made intentionally and with the aim of furthering the terrorist act or with the knowledge of the intention of the group to commit a terrorist act”. See FATF, above n 6, P. 126.

${ }^{28}$ FATF, above n 5, Para. 25.
} 
terrorist financier's unlawful intention/purpose which is relevant, and that unlawful intention/purpose must be to provide or collect funds or other assets for a terrorist organisation or individual terrorist. ${ }^{29}$

Under the FATF's guidance, the following aspects are not relevant to the scope of the terrorist financing offence:

- the purpose for which the terrorist financier intended those funds or other assets to be used by the terrorist organisation/individual terrorist;

- any knowledge that the terrorist financier may have had about how the terrorist organisation/individual terrorist was using or intending to use the funds or other assets;

- the use to which the terrorist organisation/individual terrorist actually put (or intended to put, or tried to put) the funds or other assets; and

- Whether or not the funds or other assets were used to plan, prepare for or carry out a specific terrorist act. ${ }^{30}$

This formulation casts the net of criminal liability even wider than the offence of financing terrorist acts in such a way so as to include conduct not intended to be used for a terrorist act. It appears that such prohibition is imposed due to the dangerous status of the recipient (a terrorist individual or group) of funds. Therefore, in addition to the examples listed above, the offence of financing of terrorists and terrorist groups can include the following examples:

Example 5- Selling foods to a person with the knowledge that the person is preparing for the commission of a terrorist act.

Example 6- Providing hotel services to a person designated as terrorist.

Example 7- Employing a designated terrorist to raise funds for charitable purposes.

\section{Role of Criminal law}

Before proceeding with the discussion on whether the terrorist financing offences satisfy the core principles of criminalization, the normative basis and goals of liberal criminal law will be very briefly examined. Individuals are the main components of a liberal society. The aims of a liberal society are to preserve individuals' rights and to maximize their freedom of choice. Under a liberal theory of criminal law, individuals are assumed to be self-interested, calculating

\footnotetext{
${ }^{29}$ Ibid, Para. 21.

${ }^{30}$ Ibid, Para. 22.
} 
beings who are capable of pursuing their own interests. ${ }^{31}$ Therefore, they must be free to do whatever they want to do as long as their action does not conflict with the rights and the liberty of others. ${ }^{32}$ In order to preserve liberty of individual, liberal theorists all agree that the society needs law. ${ }^{33}$

A state is the creation of individuals (the governed) who under a contract, transfer their authority of self-government to it; they give it authority to make and apply such law. ${ }^{34}$ Assuming that "individuals have in general the capacity and sufficient free will to make meaningful choices", 35 the state must treat every individual as equally responsible for their conduct to the law. ${ }^{36}$ The state is also given authority to create and enforce law which criminalizes, punishes and prevents activities which harm or damage the rights and liberty of individuals. ${ }^{37}$ States exercise this authority through its agent, the criminal justice system. However, there should be a strong justification for the enforcement of any punitive and preventive law made by a state because individuals also should be free from the arbitrary control by the state; in other words, individuals have rights not to be unjustly criminalized by the state; ${ }^{38}$ otherwise, the liberty of individuals (citizens), which is the main purpose of a liberal society, cannot be maintained and maximized.

\footnotetext{
${ }^{31}$ Alan W. Norrie Crime, reason and history : a critical introduction to criminal law (3rd edition. ed, Cambridge University Press, Cambridge ; New York, 2014), P. 35.

${ }^{32}$ Michael P. Zuckert "The virtuous polity, the accountable polity: liberty and responsibility in "the federalist"” 1992 22(1) The Journal of Federalism 123, P.124.

${ }^{33}$ Bottomley and Bronitt point out that there are "differences between liberals over permissible scope of law and the appropriate method of legal reasoning .... . Is law to be used only to provide a neutral framework within which individuals can peacefully pursue their separate ends? Or is law to be used as a tool of social engineering towards certain collective ends including collective freedoms?” See Stephen Bottomley, Simon Bronitt and Michael Kirby Law in Context (4th ed, Federation Press, Annandale, NSW, 2012), P. 5.

${ }^{34}$ Thomas Hobbes Hobbes's Leviathan (Clarendon Press, Oxford, UK, 1967) Chapter XXX.

${ }^{35}$ Andrew Ashworth and Jeremy Horder Principles of Criminal Law (7th ed, Oxford University Press, Oxford, 2013), P. 23.

${ }^{36}$ The idea of 'equality' before the law is one the main component of the rule of law. However, equality is a deeply contested concept. Bottomly and Bronitt point out that "in a crude sense, the definition of and importance attached to equality differs according to the political complexion of the liberal standpoint adopted. On the libertarian end of the spectrum, the attachment is very much to a purely formal or procedural equality-equal treatment of individuals is very much to a purely formal or procedural rather than substantive ends. As formal or strict equality promotes sameness of treatment, it may conceal the substantive political, social and economic inequality of disadvantaged groups or individuals." The opposite version of equality focus on the "quality of opportunity”. See Bottomley, Bronitt and Kirby, above n 33, P. 19. However, liberal criminal law applies to everyone equally regardless of circumstances in which they act. See Norrie, above n 31.

${ }^{37}$ The preventive function of states is theorized in accordance with Hobbes's theory of social contract. Hobbes argues "[t ] ]he very end for which this renouncing, and transferring of rights is introduced, is nothing else but the security of a man's person”. See Hobbes, above n 34, Ch.XIII.

${ }^{38}$ Dennis J. Baker The right not to be criminalized : demarcating criminal law's authority (Ashgate, Farnham, 2011), P. 56.
} 
To restrict the power of the state, the liberal theory of mid-19th century introduced the harm principle. John Stuart Mill famously said "the only purpose for which power can be rightfully exercised over any member of a civilised community, against his will, is to prevent harm to others". ${ }^{39}$ Under this view, harm to others is the only legitimate reason for state intervention. However, the application of the harm principle is not always unproblematic; the main problem with the harm principle is its ambiguity on "what 'harm' really is, conceptually and substantively" 40 or what types of harm (physical harm, harm to property, and harm to feelings or indirect harms) merits criminalization. ${ }^{41}$

The indeterminacy and breadth of the concept of harm has led liberal legal theorists, such as Joel Feinberg, to argue that the harmfulness of conduct does not alone provide a sufficient ground for criminalization; it is the wrongful (right-violating) cause of harm that makes the conduct in question deserved to be criminalized. ${ }^{42}$ Andrew Ashworth and Jeremy Horder require further tests to be fulfilled: they argue that "before criminalization is justified, not only must the conduct be morally wrong, but there must also be no strong countervailing considerations, such as absence of harm, the creation of unwelcome social consequences, the curtailment of important rights and so forth" 43

However, the perception of these requirements (harmfulness, wrongfulness, unwelcome social consequences, public wrong) may vary not only through time, but also through space (between societies). ${ }^{44}$ Ashworth and Horder accept the limits of the liberal theory of criminalization when they argue that "it remains true that key concepts such as harm, wrongdoing, and offensive may tend to melt into the political ideology of the time". ${ }^{45}$ They refer to Neil MacCormick who points out that:

Resort to the criminal law is always parasitic on or ancillary to an established legal order of rights and duties in the spheres of private law and public law. Such an order of rights and duties (et cetera) has to be founded on some (however muddled and patchwork) conception of a just ordering of society. The interests protected from invasion by criminal laws are interests

\footnotetext{
39 John Stuart Mill On Liberty (Middlesex, Harmondsworth, 1979).

${ }^{40}$ Nina Peršak Criminalising Harmful Conduct the Harm Principle, its Limits and Continental Counterparts (Springer, New York, NY, 2007), P. 14.

${ }^{41}$ Ashworth and Zedner, above n 9, P.104

42 Joel Feinberg Harm to Others; The Moral Limits of the Criminal Law (Oxford University Press, New York, NY, 1984), P. 26.

${ }^{43}$ Ashworth and Horder, above n 35. P. 29

${ }^{44}$ Lindsay Farmer "Criminal Wrongs in Historical Perspective” in Antony Duff and others (eds) The Boundaries of Criminal Law (Oxford University Press, Oxford, UK, 2010).

${ }^{45}$ Ashworth and Horder, above n 35, P. 39.
} 
legitimated by a given conception of a just social order. ... [T] he criminal law in so far as it is concerned with fending off harmful behaviour is necessarily geared to protection of what are legitimate interests according to a certain dominant political morality. ${ }^{46}$

Nevertheless, this political reality does not hinder many of liberal legal theorists from arguing that "it is still appropriate to discuss the [liberal] values and principles that ought to be relevant to criminalization decisions, since such considerations rightly play some part at various stages in the generation and refinement of reform proposals". ${ }^{47}$ Ashworth and Horder argue that

although it is true that the frontiers of criminal liability are not given but are historically and politically contingent, it remains important to strive to identify those interests that warrant the use of the criminal law and to refine notions such as harm and wrongdoings which play so prominent a part even in political discussion of these questions. ${ }^{48}$

They have identified a set of principles that, they think, ought to be considered by a liberal democratic state when determining whether and how to make conduct criminal. ${ }^{49}$ However, they do not hide the fact that these principles, which flow from either "the nature of criminal law and punishment” or "some social derivations”, may conflict in some situations or may be "contestable in their application to given facts". ${ }^{50}$ They argue, however, that these principles should influence the shaping of substantive criminal law. I will name these principles in the footnote here but avoid explaining them. ${ }^{51}$ However, I will use some of them to examine the justifiability of the offence of terrorist financing.

Now I turn to consider some of the fundamental principles that must be deployed to justify the creation, and restrain the scope of, a candidate offence. These principles include the principle of harm, the wrongful requirement, the remoteness requirement, and rule of law standards. The

\footnotetext{
46 Ibid.

${ }^{47}$ Ibid. See also Douglas N. Husak Overcriminalization : the limits of the criminal law (Oxford University Press, Oxford, 2008).

${ }^{48}$ Ashworth and Horder, above n 35, P.23

${ }^{49}$ Ibid.

${ }^{50}$ Ibid, P. 40

${ }^{51}$ General principles: the principle of Individual autonomy, the principle of welfare, the principle of harm and public wrongs. Specific principles (the minimalist approach): the principle of respect for human rights, right not to be punished, criminalization as a last resort, the principle of not criminalizing where this would be counter productive, the principle of proportionality, principles relating to the rule of law, the non-retroactivity principle, the principle of maximum certainty, the principle of strict construction, the presumption of innocence. Principles relating to the conditions of liability: the principle of mens rea, the principle of correspondence, the principle of fair labelling.
} 
purpose is to examine whether the terrorist financing offences satisfy the standard criteria of criminalization provided by these principles in liberal legal theory.

\subsection{The harm principle}

Beginning with the well-known justification, the harm principle is not only about the state's role of punishing harms. It may be linked to the state's duty of preventing harm. ${ }^{52}$ The state, under the principle of welfare, has an obligation to "create the social conditions necessary for the exercise of full autonomy by individual citizens". ${ }^{53}$ So, the harm principle of criminalization recognises a right for the society and state "to ward off crimes against itself by antecedent precautions". ${ }^{54}$ Feinberg says “[i]t is always a good reason in support of penal legislation that it would probably be effective in preventing (eliminating, reducing) harm to persons other than the actor". ${ }^{55}$ This extends the reach of criminal law beyond its punitive function by giving it a preventive role. Insisting on limiting the coercive use of power by the state, Mill sought to restrain the use of the harm principle in justifying criminalization. He asserts that conduct is not harmful if it is "merely contingent, or, as it may be called, constructive injury ... which neither violates any specific duty to the public, nor occasions perceptible hurt to any assignable individual except himself”. ${ }^{56}$ Instead, the harm in question should be "a definite damage, or a definite risk of damage, either to an individual or to the public". ${ }^{57}$

While there is less difficulty in determining the nature and gravity of a definite damage such as murder, the controversy is over what constitutes "a definite risk of damage." 58 How should such a risk be measured? What kinds of harms or risk of harms merit criminalization? Can the harm principle justify the criminalization of conduct which does not cause any harm but contributes or facilitates the commission of harm - conduct such as remote harm offences, general-public order legislation or preparatory offences? "To what extent can we hold a perpetrator liable, how far should we look for harm mediated through other actors that can still be legitimately imputed or assigned to the perpetrator?”59

\footnotetext{
52 Ashworth and Zedner, above n 9, P. 103.

${ }^{53}$ Ashworth and Horder, above n 35, p. 26.

${ }^{54}$ Mill, above n 39, P.167.

55 Joel Feinberg Harmless Wrongdoing; The Moral Limits of the Criminal Law (Oxford University Press, New York, NY, 1988), P. xix.

${ }^{56}$ Mill, above n 39, P. 149

${ }^{57}$ Ibid, P. 142

${ }^{58}$ Peršak, above n 40,P. 14

${ }^{59}$ Ibid.
} 
Given the indeterminacy and vagueness of the concept of harm, it is warned that a broad reference to the harm principle "could supply a prima facia justification for almost all of" conduct nominated for criminalization as candidate conduct may cause harm at some point, and "can be rationalized as preventing harm to others". ${ }^{60}$ A broad reference to the principle would also "erode the usefulness of the harm principle as a constraint on the state's punitive power". ${ }^{61}$ The limitation of the harm principle has resulted in the adoption of other principled restrains by criminal law theorists as grounds for criminalization.

But, before proceeding with discussion on other restraints, I would like to address my initial inquiry: is the harm principle able to provide justificatory basis for the criminalization of terrorist financing? The answer is both positive and negative. The answer is negative as the current formulation of the offence which seeks to target terrorist financing without connecting it to an immediate harm (a terrorist act) also presents a challenge for the harm principle because its attractiveness is derived "from its having been applied to more immediate harms" rather than a long-term risk of harm. ${ }^{62}$ However, the answer to the question could be positive because traditionally, the harm principle seems to have less difficulty in justifying a group of preventive offences called inchoate crimes.

In other words, criminalization of preparatory conduct is not unknown to Anglo-American criminal law. "Most systems of criminal law have some general inchoate offences" 63 (attempt, conspiracy and incitement) which adequately deal with conduct when the substantive harm is not caused yet. The main rationale for criminalization of inchoate offences is to reduce "harm by authorizing law enforcement officers and the courts to step in before any harm has been done, as long as the danger of the harm being caused is clear" ${ }^{64}$ Even though the scope of inchoate offences is controversial (controversy over "significance of intention", "relevance of impossibility", "significance of resulting harm”), ${ }^{65}$ they are defined in a way to include conduct which is connected to and has substantially facilitated a substantive offence, and/or which there

\footnotetext{
${ }^{60}$ Ashworth and Zedner, above n 9, P. 104

${ }^{61}$ A. P. Simester and Andrew Von Hirsch Crimes, harms, and wrongs : on the principles of criminalisation (Hart, Oxford, 2011), P. 53.

${ }^{62}$ Ibid.

${ }^{63}$ Ashworth and Zedner, above 9, P. 96.

${ }^{64}$ Ashworth and Horder, above n 35, P.456.

${ }^{65}$ Antony Duff Criminal Attempts (Clarendon Press, Oxford, UK, 1996), P. 142. With regard to the controversy over the scope of inchoate offences, Ashworth and Zander also make a similar point. They point out that "the ambit of all three inchoate offences [attempt, incitement and conspiracy] is controversial-for example, is it right to criminalize conduct as an attempt if the person has not yet reached the last act before committing the substantive offence?”. See Ashworth and Zedner, above n 9, P. 96-7.
} 
is a clear intention towards that substantive offence. Let's have a quick look at some of the inchoate offences’ rules and their requirements.

The law of attempts requires that "there can be a conviction even though the substantive offence that was intended is not completed and no apparent harm is caused". ${ }^{66}$ In this formulation, "the intent becomes the principal ingredient of the crime" ${ }^{67}$ because, it permits the criminalization of conduct before, and even without, the commission of the substantive harm. However, not all preparatory acts constitute attempts. Under English law and the criminal law of Australia, an act must be "more than merely preparatory to the commission of the [subsequent] offence", ${ }^{68}$ or according to United States' Model Penal Code, the act must constitute "a substantial step in the course of the conduct planned to culminate in the commission of" the subsequent offence. ${ }^{69}$ However the issue, especially with regard to incomplete attempt, is deciding when should preparatory conduct should be regarded as more than merely preparatory or a substantial step.

There are two schools of thoughts on this issue. Under a subjectivist approach,

the essence of an attempt is trying to commit a crime, and that all the law should require is proof of the intention [of the substantive offence] plus any conduct designed to implement that intention”. The reasoning is that "any person who has gone so far as to translate a criminal intention into action has crossed the threshold of criminal liability, and deserves punishment. ${ }^{70}$

Objectivists, on the other hand, argue that the law should require "proof of an act close to the commission of the substantive offence". ${ }^{71}$ Their concern is that if the scope of the offence of attempt is not restricted tightly, "any overt act [is] to suffice as the conduct element in attempts", ${ }^{72}$ This can result in increasing "wrongful arrests", conviction on the basis of the dependent's intention; “the police might be tempted to exert to obtain a confession; miscarriage

\footnotetext{
${ }^{66}$ Bernadette McSherry "Expanding the Boundaries of Inchoate Crimes; The Growing Reliance on Preparatory Offences" in Bernadette McSherry, Alan Norrie, and Simon Bronitt (eds) Regulating Deviance: The Redirection of Criminalisation and the Futures of Criminal Law (Hart Publishing, Oxford, UK, 2008), P.153

${ }^{67}$ Duff, above n 65, P.5

${ }^{68}$ Criminal Attempts Act 1981 (UK), Sec. 1 (1). Or Criminal Code Act 1995 (Australia), Sec. 11.1.2.

${ }^{69}$ Model Penal Code (US), § 5.01(1)(c).

${ }^{70}$ Jeremy Horder Ashworth's Principles of Criminal Law (8th ed, Oxford University Press, Oxford, UK, 2016), P. 479.

${ }^{71}$ Ibid.

${ }^{72}$ Ibid.
} 
of justice might increase"; and "we would be risking a world of thought crimes and thought police”. ${ }^{73}$

However, neither of these traditional justifications for attempt offences can be applied to every possible offence of financing terrorist acts. In other words, the scope and definition of the offence, according to which the act of financing, or funds raised, do not need to be linked to any terrorist act, seem to make it impossible to apply either a subjectivist approach or an objectivist approaches to justify the offence. Unlike the objectivist approach which requires criminalization of the last act which is unambiguously close to the substantive offence, the offence of terrorist financing includes any act at any a stage (e.g. buying a map, possessing information on explosive or going to the gym), even if it is not linked to a terrorist act. A subjectivist approach cannot be applied as a rational for criminalization for terrorist financing since a clear intent towards an actual, substantive offence is not required.

Similarly, the application of the harm principle to justify the offence of financing terrorists or terrorist groups is also problematic because the offence does not require criminalization of conduct which facilitates, or contributes to, preparation or commission of harmful conduct carried out by others. Traditionally, the criminalization of such conduct is justified by reference to the law of complicity or inchoate offences. For instance, the law of complicity requires that to be liable as an accomplice, there should be connection between accomplice's conduct and the principal's offence; that is, it should be shown "the accomplice's conduct helped or might have helped the principal in some way". ${ }^{74}$ In addition, the accomplice must know the essential elements of the principal's offence, or, according to the recent expansion of the UK's scope of accomplice liability, "a real possibility" that the principal will commit a certain crime or "one of a group of offences". ${ }^{75}$ A comparison between the scope of these offences with that of the offence of financing a person who intends to prepare or commit a terrorist act indicates major shift in criminalization. Consider example 5: selling food (or anything else) to a person with the knowledge that the person is planning or preparing terrorist. The seller is criminally liable regardless of whether, and how, the buyer would use the food for a terrorist act, or regardless of whether the seller intended, knew or believed the food would be used for that the commission or preparation of the terrorist act. The offence merely requires knowledge that recipient is a

\footnotetext{
${ }^{73}$ Ashworth and Horder, above n 35, P. 462.

${ }^{74}$ Horder, above n 70, P. 437.

${ }^{75}$ See Ashworth and Horder, above n 35, P. 451.
} 
person who intends to commit a terrorist offence. So the harmful consequences of the provision of the foods do not matter at all.

In a similar manner, the imposition of liability for the financing of a designated terrorist or terrorist group is not connected to any act whether harmful or harmless. Consider example 6: providing hotel services to a designated terrorist. The hotel clerk does not need to know that the designated terrorist intends to commit or prepare for any terrorist act; he does not need to intend any terrorist act to be carried out by the designated terrorist. He is liable because he simply knows that the person is a designated terrorist. This is significantly different from, for example, the law of inchoate offences (the English law of the encouraging and assisting crime) which requires that a defendant's preparatory act must be capable of assisting the commission of the subsequent offence, and that the defendant must intend, know or foresee (oblique intention) that his act facilitates its commission. ${ }^{76}$

Furthermore, while some of terrorist financing cases such as example 7 resemble conspiracy, the offence of financing a designated terrorist does not rely on the law of conspiracy to determine the harmful consequences of the financing conduct. Under the UK's conspiracy law, a person is liable for conspiratorial agreement if that

person agrees with any other person or persons that a course of conduct shall be pursued which, if the agreement is carried out in accordance with their intentions, either will necessarily amount to or involve the commission of any offence or offences by one or more of the parties to the agreement, or (b) would do so but for the existence of facts which render the commission of the offence or any of the offences impossible .... . Where liability for any offence may be incurred without knowledge on the part of the person committing it of any particular fact or circumstance necessary for the commission of the offence, a person shall nevertheless not be guilty of conspiracy to commit that offence ... unless he and at least one other party to the agreement intend or know that that fact or circumstance shall or will exist at the time when the conduct constituting the offence is to take place. ${ }^{77}$

Under such a law, the principal fund-raiser in my example would not be liable because (a) there is no conspiratorial agreement between them (meeting of minds), and (b) no harmful consequences are intended. However, under the offence of terrorist financing, the principal fund-raiser is liable for employing a designated terrorist merely because he knows he is a designated terrorist, no matter whether the designated terrorist intends the funds to be used

\footnotetext{
${ }^{76}$ See for example Part 2 of the Serious Crime Act 2007 (UK).

${ }^{77}$ Criminal Law Act 1977 (UK), Section1 (1).
} 
for a terrorist purposes, and no matter whether the principal funds-raiser knows, believes or foresees the designated terrorist may use the funds for a terrorist purposes.

\subsection{The wrongfulness requirement}

"A narrower strand of justification than the harm principle” focuses on the wrongfulness of conduct. ${ }^{78}$ Feinberg argues that

[i]t is always a good reason in support of a proposed criminal prohibition that it is necessary to prevent serious offence (as opposed to injury or harm) of persons other than the actor and would be an effective means to that end if enacted. ${ }^{79}$

Under this approach, "it is not the causing of harm that alone justifies criminalization, but the wrongful causing of harm”, ${ }^{80}$ What counts as wrongs? To Feinberg who seeks to extend the concept of harm to include wrongs, harm is "setbacks of interests that are wrongs, and wrongs that are setbacks to interest” (harmful wrongs). ${ }^{81}$ Adopting Feinberg's approach, Ashworth and Horder regard wrong as “culpably assailing a person’s interests, or abusing them by using them as a means to another's satisfaction”. ${ }^{82}$ Simester and von Hirsch regard conduct as wrongful when it treats others "with a gross lack of respect or consideration". ${ }^{83}$

Many legal moralists agree that wrongfulness is a prerequisite but not a sufficient requirement for criminalization; therefore, not all moral wrongs (such cheating at games or lying) are the subject of criminal law. ${ }^{84}$ A wrong must be regarded as publicly wrong. The "public" element does not only include acts which "harm or wrong the public collectively or the polity as a whole” (crimes such as tax evasion, treason), but also wrongs which, although committed in private and harm individuals without impacting "the wider world" (crimes such murders and rapes), concern all of us as wrongs against the values we share. ${ }^{85}$ Duff defines public wrongs as the "concern of all citizens in virtue of their shared membership of the polity". ${ }^{86}$ On the other hand, there is some conduct that is not pre-legally wrongful (or malum in se) but regarded

\footnotetext{
${ }^{78}$ Ashworth and Zedner, above n 9, P. 106

${ }^{79}$ Feinberg, above n 55, p. xix.

${ }^{80}$ Ashworth and Horder, above n 35, P.29

${ }^{81}$ Feinberg, above $\mathrm{n}$ 42. P. 36

${ }^{82}$ Ashworth and Horder, above n 35, P. 29.

${ }^{83}$ A. P. Simester and Andrew Von Hirsch Incivilities : regulating offensive behaviour (Hart, Oxford, 2006), P. 142.

${ }^{84}$ See for example, Simester and Von Hirsch, above n 61, P. 26.

${ }^{85}$ Antony Duff Answering for crime : responsibility and liability in the criminal law (Hart, Oxford ; Portland, Or., 2007), P. 141.

${ }^{86}$ Antony Duff "Perversions and Subversions of Criminal Law" in Antony Duff and others (eds) The

Boundaries of the Criminal Law (Oxford University Press, Oxford, UK, 2010), PP.88-9.
} 
as wrongful because they are prohibited by law (mala prohibita) - conduct such as such as traffic offences.

In short, in the criminalization of conduct as wrongful, a following general principle should be followed:

"when labelling conduct as wrongful, and when labelling those it convicts as culpable wrongdoers, the state should get it right. In particular, the criminal law contains a general limiting principle that D[efendent] should not be convicted of an offence unless he is responsible for a wrong. Any formal judgment of blame, including the finding of guilt on which the conviction is based must be predicated upon norm-violating conduct. One cannot blame a person unless that person does something that, all things considered, she ought not to do. ${ }^{87}$

Applying this requirement to the offence of terrorist financing, the question is where the wrongfulness of the offence is derived from? Let me narrow down the question: is collecting a map, possessing information on explosives, purchasing a weapon, selling foods, offering hotel services, employing a designated terrorist, or sending money to a family member wrongful? How do these actions set back the interests of others? How can we justify the criminalization of terrorist financing by reference to the wrongfulness requirement?

There is no doubt that committing a terrorist act is a harmful wrong in the sense of setting back to others' interests (make them worse off) and treating them "with a gross lack of respect or consideration”, ${ }^{88}$ Financing of a terrorist act, although not harmful, can be justified as wrongful due to its connection with the harmful act of terrorism. So, its wrongfulness is contingent; that is, it is wrongful because it is correlated with the preparation or commission of a terrorist act.

But this is not what the definition of the terrorist financing offence implies. It should be remembered that FATF diffuses the idea that terrorist financing includes cases where "no terrorist act was in fact carried out or attempted ... or ... no specific act had been planned; or ... the funds or other assets intended for use in a terrorist act were in fact used for some other activity”. ${ }^{89}$ What this formulation implies is that any financing conduct (collection, possession or provision) carried out with the intent to further a terrorist act should be criminalized. So, it is neither the harmful prospect of financing conduct, nor the financers' mental state towards a terrorist act which makes the act of financing wrongful; instead, the financer's mere intent to

\footnotetext{
${ }^{87}$ Simester, above n 15, P.67

${ }^{88}$ See Simester and Von Hirsch, above n 83, P. 142.

${ }^{89}$ FATF, above n 5, Para. 56.
} 
commit a terrorist act makes the act of financing criminalizable; but the question is whether bad intent can make conduct wrongful? If so, when?

In response to this question, Simester draws a distinction between three categories of conduct: “inherently innocent” "morally ambiguous" and "inherently wrongful”. With regard to inherently innocent conduct, he argues that

a criminal prohibition constitutes, inter alia, an official pronouncement that the activity is morally wrongful _ qua activity, and not just on particular occasions. Where the proscribed activity is not wrongful, it follows that the state is not telling the truth and criminalisation is prima facia unjustified. Hence the state should not prohibit, and label as criminal ... inherently innocent conduct. ... The thought here is that [such an activity] is simply not wrong, and its normative status ... cannot be infected by the further intentions with which it is done. ${ }^{90}$

He also points out that "the prospect of future wrongdoing does not seem to supply any significant reason as to why we should not do those activities, any reason that we might remark upon. The risk of facilitating such wrongdoing is too ancillary, especially where the conduct is otherwise quinidine and harmless". ${ }^{91}$ These rule out the criminalization of otherwise harmless conduct such as buying a map, going to the gym, selling a car, offering hotel services and employing a designated terrorist.

With regard to the morally ambiguous conduct the character of which "cannot be determined by reference to its external, actus reus feature alone” (e.g. picking up a wallet lying in the street), Simester argues that the mens rea requirement of an offence "may suffice to restrict its application to activities that are indeed wrongful” (e.g. picking up the wallet in order to keep it $v$. picking up the wallet in order to hand it over to a nearest police station). ${ }^{92}$ While this satisfies the wrongfulness requirement in the cases where the mental element of the offence is clearly and closely directed to the substantive offence (e.g keeping the wallet), such a connection in the terrorist financing offence is missing. So, the criminalization of the possession of information on explosives (example 2) or any other articles which have a legal as well as illegal function is not justifiable unless their application is restrictively limited to a specific activity intended by the possessor. Needless to say that such a requirement rules out the offence of financing designated individuals or groups, which does not link to any wrongful conduct.

\footnotetext{
90 Simester, above n 15, P.74

91 Ibid, P. 74-5.

92 Ibid.
} 
In respect of "inherently wrongful”, Simester argues that there are some activities whose nature indicates their wrongfulness. His example is the purchase of a police radar detector. He argues that "one cannot regard the use of radar detectors as incidental or ancillary, and unconnected to its purposes". ${ }^{93}$ So, their purchase or possession is wrongful and must be subject of criminal law due to its core function, regardless of whether there is any harmful act is planned or attempted. Can this approach be used to justify the financing cases when the financers are involved in illegal acts?

Let's examine the example 2. A person purchases some explosives to use them in a bank robbery. The person wants to use the robbed money for the commission or preparation of a terrorist act. According to the Simester's argument, the purchase of the explosives is wrongful as it will be used for damaging another's property (a bank). But is it accurate to argue that it is wrongful because of its direct connection to the bank robbery? Or should we conclude that it is wrongful because of the ulterior intent of the person (using the money for commission or preparation of a terrorist act)? What if the person will change his mind after the bank robbery and will not proceed with his plan of committing, or preparing for, a terrorist act? Is it fair to regard his act of purchasing the explosives as terrorist financing? It seems, at least to me, that such labelling is not consistent with the principle of fair labelling which requires offences must be "subdivided and labelled so as to represent fairly nature and magnitude of the law breaking”. 94

\subsection{The nexus requirement}

As mentioned, the offence of terrorist financing does not follow the traditional pattern of criminalization as it permits criminalization of financing cases where connection between financing conduct and a terrorist act is blur. This poses, what Simester calls, "remoteness problems”. Simester distinguishes between two types of remoteness; remoteness with regard to the "nexus" between the preparatory conduct and the substantive offence for which the preparatory conduct is carried out, and remoteness in relation to distance between these two. ${ }^{95}$

\subsubsection{Remoteness of the nexus}

In relation to the former, he argues that

\footnotetext{
93 Ibid, P.75.

94 Ashworth and Horder, above n 35, P. 77.

${ }^{95}$ Simester, above n 15, P. 67.
} 
the nexus requirement ... addresses the connection between risks of $\mathrm{Y}$ and doing of $\mathrm{X}$, such that doing $\mathrm{X}$ with the intent to do $\mathrm{Y}$ becomes wrong. Its point is that the connection is established when there is a nexus between the doing of $\mathrm{X}$ and the intent to do (or, perhaps, facilitate) Y. If I am walking the streets today, having resolved to murder my brother tomorrow, that connection is lacking - unless my actions today are part of my project for tomorrow. ${ }^{96}$

Unlike the offence of financing terrorists or terrorist groups, the offence of financing terrorist acts seems to satisfy this requirement since, for example, the purchase of a map or possessing of information on how to make explosives is part of a terrorist attack which may (or may not) be executed at some point. However, in practice, the offence raises evidential and human rights concerns; the main question here is: when there is no terrorist act involved, how can a court determine that the purchase of map or having information on explosives is part of [future] a project? A defendant may have a terrorist intention, but how can a court determine with sufficient certainty that the purchase of a map or possession of the information is related to a terrorist act, or will be used for the commission or preparation of a terrorist act which may not be planned yet? In the absence of any real connection between financing conduct and an actual terrorist act, the offence seems to require the imposition of liability based on the presumption that these acts may be related to a terrorist act. This approach is in obvious contradiction with a fundamental principle of procedural fairness in the criminal law or the presumption of innocence which requires proof of guilt beyond reasonable doubt, not shadow of doubt. ${ }^{97}$

What if "the defendant's conduct gives good ground for suspecting that the risk of some

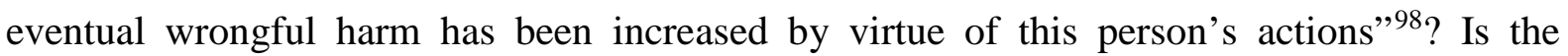
prosecution of such conduct justified if the law gives the defendant an opportunity (defence) to prove and reassure a court, the state and fellow citizens that his suspicious behaviours are nothing to do with commission or facilitation of any terrorist act (an evidential burden)? ${ }^{99}$ The question then arises: when there is no terrorist act planned or attempted, with regard to what terrorist act should the suspect provide evidence to avoid liability? Even if, as Duff argues,

\footnotetext{
96 Ibid, P. 68.

${ }^{97}$ Ashworth and Horder, above n 35, P. 71.

${ }^{98}$ Peter Ramsay "Democratic limits of preventive criminal law” in Andrew Ashworth, Lucia Zedner, and Patrick Tomlin (eds) Prevention and the limits of the criminal law (Oxford University Press, Oxford, 2013), P, 216.

99 This approach has been taken by English law where, in Section 57(1) of the Terrorism Act 2000 (UK), "a person commits an offence if he possesses an article in circumstances which give rise to a reasonable suspicion that his possession is for a purpose connected with the commission, preparation or instigation of an act of terrorism. Section 57 (2), however, states that "[i]t is a defence for a person charged with an offence ... to prove that his possession of the article was not for a purpose connected with the commission, preparation or instigation of an act of terrorism.”
} 
[w]e can make normative sense of this procedural structure by thinking about what it is reasonable to expect citizens to answer for in a criminal court, [it would be] on the pain of conviction and punishment if they cannot offer an exculpatory answer. They can be expected to answer for what we call 'presumptive wrongs' - conduct that the court can probably conclude or presume to have constituted a culpable public wrong in the absence of an exculpatory explanation of it. ${ }^{100}$

In addition, Peter Ramsay warns that the enforcement of such a law results in "mass routine surveillance" which seeks "to identify the dangerous intentions that may be lurking there". ${ }^{101}$ The effect of such a law is also to make "the distribution of criminal liability more dependent on executive discretion (formally so in respect of preventive orders), and to extend the scope of executive surveillance and coercion into the most private areas of individual subject's existence”. ${ }^{102}$

\subsubsection{Remoteness and the distance problem}

The second sense of remoteness concerns with the problem of distance between preparatory conduct and the subsequent act. ${ }^{103}$ Ashworth and Zender argue that "even if a sufficient nexus between $\mathrm{X}$ and $\mathrm{Y}$ is established in the particular case, $\mathrm{X}$ may still be too distant from $\mathrm{Y}$ to justify criminal liability”. ${ }^{104}$ The offence of financing terrorist acts surely fails to pass this test as it targets conduct very far from any terrorist act. Similarly, the offence of financing of terrorists or terrorist groups does not satisfy this requirement as criminal liability can be imposed merely because the status of recipient(s) of funds is regarded by the state or UN Sanction Committee as dangerous.

In the support of such an approach, one may raise the argument that the gravity of the offence of terrorism requires and justifies the early intervention and criminalization of any preparatory conduct which may lead to a terrorist act. Why should a connection between preparatory acts and a terrorist act matter? Why should we adhere to the nexus requirement and demand criminalization of conduct which "comes close to the actual commission of the offence" and not "merely conduct undertaken with intent to commit an offence?" ${ }^{105}$ Duff argues that

\footnotetext{
${ }^{100}$ Duff, above n 86, P. 96.

${ }^{101}$ Ramsay, above n 98, P. 218

102 Ibid, P. 219.

103 Simester, above n 15, P. 69

${ }^{104}$ Ashworth and Zedner, above n 9, P. 111.

105 Duff, above n 65, P. 387.
} 
An initial answer is that the law should leave intending criminals a locus poenitentiae: the chance to decide for themselves to abandon their criminal enterprises. This matters, because the law should treat and address its citizen as responsible agents. The central value to which this answer appeals is that of individual freedom to determine one's own action. We must look more carefully at the character of that value. From one, roughly consequentialist, perspective, individual freedom is a good which the law should seek to maximize. That is, the law should aim to secure to every citizen the maximum possible freedom to determine her own actions and future, by her own choices. ${ }^{106}$

Do preparatory offences like terrorist financing fulfil this commitment? Simester argues the approach taken to deal with preparatory offences rests on idea that

focuses on the lack of trust and respect exhibited by a state that pre-emptively regulates conduct. ... At the core of any decent legal system is a commitment to respect the dignity of those it governs, to treat them as reasoning human beings. Preparatory crimes undermine that commitment. ${ }^{107}$

So do terrorist financing offences.

\subsection{Rule of law standards}

An offence cannot be justified unless it satisfies the fundamental principles and values of the rule of law. A minimum respect for the principle of autonomy requires citizens to "be informed of the law before it can be fair to convict them of an offence”. ${ }^{108}$ The principle of maximum certainty requires that "criminal laws should be drafted with as much certainty as possible, so as to clarify the boundaries of the criminal sanction, both for individuals and courts”. ${ }^{109}$ The law must also "avoid taking people by surprise, ambushing them, putting them into conflict with its requirements in such a way as to defeat their expectations and to frustrate their plans." ${ }^{110}$ How consistent the offences of terrorist financing are with these principles will not be discussed here. But I will briefly discuss some controversial elements of the offence here.

Under the Terrorist Financing Convention, the offence of terrorist financing prohibits unlawful and wilful collection or provision of funds with the intent that the funds are to be used, in order

\footnotetext{
106 Ibid.

107 Simester, above n 15, P. 70.

${ }^{108}$ Ashworth and Horder, above n 35, P. 56.

${ }^{109}$ Ashworth and Zedner, above n 9, P. 113.

${ }^{110}$ John Gardner "Introduction” in H. L. A. Hart and John Gardner (eds) Punishment and responsibility : essays in the philosophy of law (2nd ed, Oxford University Press, Oxford, 2008), P. xxxvi.
} 
to carry out commission or preparation of a terrorist act. ${ }^{111}$ However, this formulation of the offence does not satisfy rule-of-law values for the following reasons.

The first issue is related to the definition of terrorism. Internationally, there is no consensus on a generic definition of terrorism. No international convention has defined 'terrorist group'. States' definitions of terrorism are different from one another. In some countries (such as the United Kingdom), terrorism has been defined so broadly that includes conduct which does not inflict violence. ${ }^{112}$ A state may have several definitions of terrorism. ${ }^{113}$ Terrorist Financing Convention defines terrorism as an act "intended to cause death or serious bodily injury to a civilian, or to any other person not taking an active part in the hostilities in a situation of armed conflict, when the purpose of such act, by its nature or context, is to intimidate a population, or to compel a government or an international organization to do or to abstain from doing any act”. ${ }^{114}$ Nonetheless, this definition does not precisely clarify what types of conduct, by whom, in what circumstances and when, against whom (targets or victims) and with what intention or motivation ought to be considered terrorism? ${ }^{115}$

So, if a definition of terrorism suffers from a certain degree of ambiguity, it is not surprising that any terrorist-related offences would be ambiguous. In other words, if financing with the intent to bring about a terrorist act is the subject of criminal law, there should be a clear understanding of what constitutes terrorism the financing of which is urgently sought to be tackled. This causes problems especially because terrorism is

\footnotetext{
111 Terrorist Financing Convention, Article 2.1.

112 Terrorism Act 2000 (UK), Section 1, an act is regarded as terrorist if it "is designed seriously to interfere with or seriously to disrupt an electronic system”.

113 See for example in the United States (18 U.S. Code $\S 233$, Chapter 113(B)), terrorism is defined as "violent acts or acts dangerous to human life that are a violation of the criminal laws of the United States or of any State ... appear to be intended t (i) to intimidate or coerce a civilian population; (ii) to influence the policy of a government by intimidation or coercion; or (iii) to affect the conduct of a government by mass destruction, assassination, or kidnapping; and...(C) occur primarily within the territorial jurisdiction of the United States...”. Unlike this definition, the Federal Bureau of Investigation (FBI) considers damage to private property a terrorist act if they carried out with "political or social” purposes (See FBI, “Terrorism 2002/2005”,

$<$ https://www.fbi.gov/stats-services/publications/terrorism-2002-2005 > viewed at 22 Feb, 2017). The

Department of Homeland Security's definition has much emphasis on the damage or threat to "critical infrastructure or key resources" (See the Department of Homeland Security, "Homeland Security Presidential Directive 7: Critical Infrastructure Identification, Prioritization, and Protection”,

<https://www.dhs.gov/homeland-security-presidential-directive-7 > viewed at 23 Feb2017). The US

Department of Defence's definition of terrorism has more emphasis on the use of threat "to instil fear and coerce the government or society" (see "Department of Defense Dictionary of Military and Associated Terms, 8 November 2010; As Amended Through 15 February 2016” <

http://www.dtic.mil/doctrine/new_pubs/jp1_02.pdf> viewed at 22 Feb 2017).

114 Terrorist Financing Convention, Article 2.1(b).

${ }^{115}$ Hamed Tofangsaz "Terrorism or not terrorism? Whose money are we looking for” 2015 22(3) Journal of Financial Crime 378.
} 
regarded as a transnational offence which transcends international borders and transgresses the laws of several states, and which needs a close and harmonised cooperation to be prevented. The absence of an agreement on a generic definition of terrorists, or a lack of consensus on distinction between terrorists and freedom fighters can lead to massive variation in the application of terrorist offences, in the violation of the rule of law.

Secondly, the conduct element of the offence is both vague and broad. It is vague because it is arguable whether the act of collection is prerequisite to the act of provision, or there are two different, but successive offences? That is, if a person collects funds in order to provide them, is it an inchoate crime or complete one? Is it also controversial what 'unlawful' collection or provision of funds means? Under what circumstances, or when, is financing of a terrorist act or an individual terrorist or an organization lawful? The conduct element is also very broad. The Convention defines term "funds" in the way to include almost everything: monetary as well as non-monetary articles. ${ }^{116}$ In the US, funds include tangible goods, “training”, “personnel”, “transportation”, "service” and "expert advice or assistance”. ${ }^{117}$ So, it is controversial how giving advice to a terrorist group about "how to petition the United Nations to seek redress for human rights violations" is considered a criminal act. ${ }^{118}$

Thirdly, a general principle of the rule of law requires that citizens have "fair opportunity to exercise the capacity for doing what the law requires and abstaining from what it forbids". 119 Central to this principle is the principle of mens rea, which states that "criminal liability should impose on persons who are sufficiently aware of what they are doing, and of the consequences it may have, that they can fairly be said to have chosen the behaviour and its consequences”. ${ }^{120}$ That the offence can be committed without connection to, or the existence of a terrorist act disregards this rule of law value. In other words, in the absence of such connection the question arises as to what a financer should know or intend to be criminally liable? According to the FATF's recommendations, "terrorist purposes" is the mental element; ${ }^{121}$ however, it is also

\footnotetext{
${ }^{116}$ According to Article 1 (1) of Terrorist Financing Convention, "funds means assets of every kind, whether tangible or intangible, movable or immovable, however acquired, and legal documents or instruments in any form, including electronic or digital, evidencing title to, or interest in, such assets, including, but not limited to, bank credits, travellers cheques, bank cheques, money orders, shares, securities, bonds, drafts, letters of credit”. 11718 U.S.C. $\S \S 2339 \mathrm{~A}$ and B.

118 See for example Humanitarian Law Project v. Gonzales 380 F.Supp.2d 1134(United States District Court, C.D. California, Western Division, 2005), Para. 1152.

${ }^{119}$ Ashworth and Zedner, abobe n 9, P. 113-4.

${ }^{120}$ Ashworth and Horder, above n 35, P. 155

${ }^{121}$ FATF, above n 5, Para. 15.
} 
unclear what constitutes "terrorist purposes”? To sum up my arguments about the definition of the offence, if "criminal law should operate so as to guide people away from certain courses of conduct, and should provide for the conviction only of persons who intend or knowingly risk the prohibited consequences", ${ }^{122}$ it is not wrong to conclude that the current formulation of the terrorist financing offences, applied and advocated by liberal states, fails to play such a role.

Lastly, the over-inclusiveness of an offence concerns the rule of law. Ashworth and Zender argue that "it is contrary to principle to provide for the criminalization and punishment of conduct that is significantly broader than the wrong it is aimed to prevent." ${ }^{23}$ Referring to Husak's argument of over-criminalization, ${ }^{124}$ they argue that it risks "a presumption against over-inclusive criminal law, explaining that an over-inclusive law is one whose justificatory rationale applies to some but not all of the conduct it proscribes”. ${ }^{125}$ The offence of terrorist financing is a good example of over-inclusiveness. The offence permits the criminalization of conduct even before a terrorist act is planned. Such an early intervention, leads to laying liability on people before they determine whether and how they may commit a terrorist act. This is contrary to the principle of individual autonomy which underpins the liberal view that "individuals should be treated as capable of changing their mind and conforming to the criminal law, because this is what it is to respect him as a responsible agent”. ${ }^{126}$

Regarding the financing of a terrorist or a terrorist group, the offence stretches the boundaries of criminal law beyond the preventive role of criminal law by prohibiting conduct carried out with no bad intention (e.g. financing designated individuals or groups). The FATF justifies such criminalization by arguing that funds can be used by a terrorist organization for different purposes such as "propaganda and recruitment, training, salaries and member compensation, and social services. Funds provided for and spent on these non-attack activities nevertheless contribute to terrorist attacks, by sustaining the terrorist organisation's capability to mount such attacks”. ${ }^{127}$ While there may be some truth in this argument, the use of criminal law in such a vague and broad way can turn the law into a sweeping tool which targets a broad range of conduct assumed to contribute the sustainability of terrorist groups. ${ }^{128}$ So, it is not surprising

\footnotetext{
${ }^{122}$ Ashworth and Zedner, above n 9, P. 114

123 Ibid, P. 113.

124 See Husak, above n 47.

${ }^{125}$ Ashworth and Zedner, above n 9, P.113.

${ }^{126}$ Ibid, P. 110

${ }^{127}$ FATF, above n 5, Para. 19.

128 “A well-known example, though not a typical one, is of Rizwaan Sabir, the University of Nottingham student who in 2008 downloaded the Al-Qaida training manual from the US Justice Department website in order to
} 
that, if the law on terrorist financing is interpreted loosely, I am criminally liable for intentionally writing this while I know that terrorist groups may read it and use its arguments in their propaganda against liberal states which have established, support and diffuse a law on terrorist financing which actually contradicts their fundamental principles of criminalization and which violates human rights.

\section{Conclusion}

Prevention of provision of funds to those who commit terrorist acts is a good idea. However, this requires a clear definition of terrorist acts, terrorists and terrorist organizations. Being certain on the scope and nature of terrorism, then we need to response to another question: is the criminal law a proper tool to be deployed in countering terrorist financing?

It should be noted that criminal law is "a censuring and preventive mechanism” but not the only one. ${ }^{129}$ It is the "the strongest formal censure that society can inflict"; ${ }^{130}$ so it should be used as a last resort. ${ }^{131}$ "Morality, social convention”, “peer pressure”, “civil liability” and "administrative regulation" are other sources of regulating suspicious and unwelcomed behaviour. ${ }^{132}$ Whether terrorist financing is one of the behaviours that can be dealt with more effectively by one of these mechanisms was beyond the scope of this research. My focus, instead, was the justifiability of the criminalization of terrorist financing as an independent offence in terms of existing notions of criminalization.

Terrorist financing cannot be criminalized without being connected to an actual terrorist act and still adhered too liberal principles of criminalisation. Financing conduct in many cases is so innocent and ancillary that its criminalization cannot be justified on these principles. Its criminalization violates liberal criminal law principles and values, as discussed here, and raises regulatory problems and human rights concerns, as discussed somewhere else. ${ }^{133}$

The sad part of the story is that liberal Western states and inter-governmental organizations backed by them insist the offence must be adopted transnationally and implemented rapidly.

\footnotetext{
research his choice of thesis, and found himself detained for several days in a police station, along with a University employee, on suspicion of the commission, preparation or instigation of acts of terrorism. He eventually won his action for false imprisonment”. See Anderson QC, above n 7, P. 10.

${ }^{129}$ Ashworth and Horder, above n 35, P. 33.

130 Ibid, P.1.

${ }^{131}$ Ibid, P. 33

132 Ibid.

133 Tofangsaz, above n 21.
} 
States, including those with low or no respect for democratic values, have started embedding the offences in their domestic law. ${ }^{134}$ The point is that, if the terrorist financing offence violates the fundamental principles on which criminal law is based, or disturbs protected individuals rights in countries where those rights and democratic values are highly respected and promoted, its draconian impacts on the life of those who live and are ruled by authoritarian or dictatorial states will be catastrophic. Whether or not it is the time to rethink the offences of terrorist financing should be left to legislators and international policy makers to decide. This paper, however, has raised serious doubts on the compatibility of the offences with some of nonnegotiable, fundamental principles of criminalization. I have not spent much time evaluating the arguments in favour of the offence as I believe any argument in favour is invalid as long as the offence does not satisfy the requirements of these principles.

${ }^{134}$ Hamed Tofangsaz “Confiscation of Terrorist Funds: Can the EU Be a Useful Model for ASEAN?” 2017 34(2) Pacific Basin Law Journal 149. 